\title{
Desorption isotherms of flaxseeds (Linum usitatissimum L.) and thermodynamic parameters of the process ${ }^{1}$
}

\author{
Isotermas de dessorção de sementes de linhaça (Linum usitatissimum L.) e parâmetros \\ termodinâmicos do processo
}

\author{
Maria da Conceição da Costa Valente ${ }^{2}$, Rafael Alves do Nascimento ${ }^{3 *}$, Elza Brandão Santana², Lênio José \\ Guerreiro de Faria ${ }^{2}$ and Cristiane Maria Leal Costa ${ }^{2}$
}

\begin{abstract}
Sorption isotherms of flaxseeds were determined by static gravimetric method at temperatures 40,60 , and $80{ }^{\circ} \mathrm{C}$, over a relative moisture range of $10-95 \%$. Six mathematical models were applied to analyze the experimental data. The modified GAB model showed the best fitting to the experimental data. The isosteric heat and differential entropy were determined by applying the Clausius-Clapeyron and Gibbs-Helmholtz equations, respectively. The isosteric heat and the entropy of desorption isotherm presented similar behavior, with a sharp change of $10 \%$ in the equilibrium moisture content. The enthalpy-entropy compensation theory was applied to the isotherms, indicating that they are enthalpy-controlled.
\end{abstract}

Key words: Equilibrium moisture content. Drying. Isosteric heat.

RESUMO - As isotermas de sorção das sementes de linhaça foram determinadas pelo método gravimétrico estático nas temperaturas de 40,60 , e $80{ }^{\circ} \mathrm{C}$, no intervalo de umidade relativa de $10-95 \%$. Foram aplicados seis modelos matemáticos para analisar os dados experimentais. O modelo de GAB modificado mostrou-se o melhor ajuste aos dados experimentais. A entalpia e a entropia diferencial de dessorção foram estimadas através das relações de Clausius-Clapeyron e Gibbs-Helmholtz, respectivamente. O calor isostérico e a entropia da isoterma de dessorção apresentaram comportamento semelhante, com uma acentuada alteração no teor de umidade de equilíbrio de 10\%. A teoria da compensação entalpia-entropia foi aplicada às isotermas, indicando que elas são controladas por entalpia.

Palavras-chave: Conteúdo de umidade de equilíbrio. Secagem. Calor isostérico.

\footnotetext{
DOI: $10.5935 / 1806-6690.20200021$

*Author for correspondence

Received for publication 31/01/2018; approved on 21/10/2019

${ }^{1}$ Parte da Dissertação do primeiro autor apresentada ao Programa de Pós-Graduação em Engenharia Química da Universidade Federal do Pará/UFPA

${ }^{2}$ Programa de Pós-Graduação em Engenharia Química/PPGEQ, Universidade Federal do Pará/UFPA, Belém-PA, Brasil, valentemcc@yahoo.com. br (ORCID ID 0000-0002-3547-3153), santanaeb@ yahoo.com.br (ORCID ID 0000-0001-7726-5865), leniojgfaria@ gmail.com (ORCID ID 00000002-9534-9998), cristianemlcosta@gmail.com (ORCID ID 0000-0002-3451-1234)

${ }_{3}^{3}$ Programa de Pós-Graduação em Engenharia dos Recursos Naturais da Amazônia/PRODERNA, Universidade Federal do Pará/UFPa, Belém-PA, Brasil, Rua Augusto Corrêa, 01, Campus Universitário do Guamá, Belém-PA, Brasil, 66.075-110, rafaelnascimentoa@gmail.com (ORCID ID 0000-0002-5803-9042)
} 


\section{INTRODUCTION}

Flaxseed (Linum usitatissimum L.) belongs to the linseeds family and is considered a functional food because, in addition to its basic nutritional functions, it contains substances that can prevent several diseases, including degenerative and cardiovascular diseases. It is also the primary food source of lignans, phytochemical compounds similar to estrogen, which may contain anticarcinogenic properties, mainly toward breast and colon cancers (KAJLA; SHARMA; SOOD, 2015). Flaxseed also has anti-inflammatory qualities owing to its antibacterial properties. It is rich in soluble fibers and approximately $40 \%$ of its oil weight is rich in $\mathrm{n}-3$, including $\alpha$-linolenic (omega-3) (CHOO; BIRCH; DUFOUR, 2007).

The moisture sorption isotherm is a valuable tool used to determine the ideal moisture content and assess the storage and drying conditions of biological products. Good knowledge of the relation between hygroscopic equilibrium and water activity $\left(\mathrm{a}_{\mathrm{w}}\right)$ is essential to describe the drying process and equipment optimization (ANDRADE; LEMUS; PEREZ, 2011; BOTHEJU; AMARATHUNGE; ZIYAD MOHAMED, 2008). The sorption isotherms are also useful in foreseeing the stability of service life in relation to the physical composition, biochemistry, and microbial stability of biomaterials. Such aspects are essential to determine the quality criteria of the dry product, in addition to being indispensable in the development and quality control processes (MAZZA; JAYAS; WHITE, 1990).

Thermodynamic properties may be used to estimate the minimal energy required for drying, and they provide information about the state of the water in the product. Determining these properties is necessary when the rate of water sorption is given as a function of a simultaneous process of heat and mass transference to predict kinetics parameters and to make approximations of the microstructure and the physical changes that occur on the surface of the product (GONELI et al., 2016).

The integral isosteric heat of sorption $\left(Q_{\mathrm{st}}\right)$ indicates the state in which water is blended with the biological material, indicating the strength of the molecular binding of water to the sorption sites, which is used in design calculations of dryers that provide more heat than the pure water latent vaporization heat ( $\gamma$ vap) to dry the material to having lower moisture contents (CABEZA; SOLÉ; BARRENECHE, 2017). Entropy is associated with blending or repulsion of the forces in the system, being related to the spatial arrangement of the relationship between solvent and solute, or characterizing or defining the degree of order or disorder present in the system considered (MIANOWSKI; URBAŃCZYK, 2017).
This work was conducted to experimentally determine the moisture desorption isotherms of flaxseeds at 40,60 , and $80^{\circ} \mathrm{C}$, by selecting the mathematical model that best describes the hygroscopic behavior at those temperatures, estimating the thermodynamic properties (enthalpy and differential entropy), and assessing the applicability of the enthalpy-entropy compensation theory.

\section{MATERIAL AND METHODS}

The experiments to obtain the equilibrium moisture values were conducted using flaxseeds (Linum usutatissimum L.), a brown variety, acquired in the Belem City market in the State of Pará, Brazil. After purchase, the seeds were taken to the Laboratory of Drying and Recovering of Particles, LSRP, of the UFPA Chemistry Engineering and stored at room temperature, approximately $27^{\circ} \mathrm{C}$, until processing.

To determine the equilibrium moisture of the flaxseed at temperatures of 40,60 , and $80{ }^{\circ} \mathrm{C}$, we used the static gravimetric approximation method, as recommended by the European Project COST 90 for adequate determination of the physical properties of foods (SPIESS; WOLF, 1983). In Table 1, a list of the salts used and the corresponding water activities generated for each service temperature, is shown.

To determine the water constants, we used saturated saline solutions, prepared by addition of impurity free heated water $\left(80^{\circ} \mathrm{C}\right)$, over a portion of salt, until saturation, in a proportion of 1:80 (mass of sample: volume of solution), until the formation of a liquid layer of approximately $2 \mathrm{~mm}$ (GREENSPAN, 1977; LABUZA, 1983).

The flaxseeds, weighing approximately $1 \pm 0.05 \mathrm{~g}$, were placed in polyethylene containers $(50 \mathrm{~mL})$, which, after weighing, were stored in hermetic pots with the salt solutions generating the respective water activities desired. The hermetic pots were placed in incubators at controlled temperatures of 40,60 , and $80^{\circ} \mathrm{C}$, where they were retained until constant weight was reached, verified using periodical weighing on analytical scales (Choy model 200L, Japan). All the assays were performed in quadruplicate. The mass of dry solid necessary for calculating the moisture equilibrium content of the samples was determined in an oven with forced air circulation (Fabbe model) at $105^{\circ} \mathrm{C}$ for $24 \mathrm{~h}$, according to standardized methodology (HORWITZ, 2005).

The experimental data of the equilibrium water content were assessed by six mathematical models, summarized in Table 2, and the typical constants were determined through non-linear regression techniques. 
Table 1 - Values of $a_{w}$ generated by saturated saline solutions at the temperatures studied

\begin{tabular}{cccc}
\hline Salts & \multicolumn{3}{c}{ Water activities (aw) } \\
\cline { 2 - 4 } & $40{ }^{\circ} \mathrm{C}$ & $60{ }^{\circ} \mathrm{C}$ & $80^{\circ} \mathrm{C}$ \\
\hline $\mathrm{NaOH}$ & 0.626 & 0.361 & - \\
$\mathrm{LiCl}$ & 0.112 & 0.109 & 0.105 \\
$\mathrm{MgCl}_{2} \cdot 6 \mathrm{H}_{2} \mathrm{O}$ & 0.316 & 0.293 & 0.260 \\
$\mathrm{~K}_{2} \mathrm{CO}_{3}$ & 0.433 & 0.421 & 0.411 \\
$\mathrm{NaNO}_{2}$ & 0.710 & 0.673 & 0.652 \\
$\mathrm{NaCl}$ & 0.747 & 0.745 & 0.763 \\
$\mathrm{KCl}$ & 0.823 & 0.802 & 0.789 \\
\hline
\end{tabular}

- values $<0.01$

Table 2 - Mathematical models used to assess the sorption isotherms

\begin{tabular}{ccc}
\hline Models & Equations & $\mathrm{N}^{\mathrm{o}}$ \\
\hline Peleg & $\mathrm{X}=\mathrm{K}_{1} \alpha_{\mathrm{w}}{ }^{\mathrm{N} 1}+\mathrm{K}_{2} \alpha_{\mathrm{w}}{ }^{\mathrm{N} 2}$ & $(1)$ \\
Modified Oswin & $\mathrm{X}=(\mathrm{A}+\mathrm{BT})\left[\alpha_{\mathrm{w}} / 1-\alpha_{\mathrm{w}}\right]^{1 / \mathrm{c}}$ & $(2)$ \\
Modified Henderson & $\mathrm{X}=\left[-\ln \left(1-\alpha_{\mathrm{w}}\right) / \mathrm{A}(\mathrm{T}+\mathrm{B})\right]^{1 / \mathrm{c}}$ & $(3)$ \\
Modified Halsey & $\mathrm{X}=\left[-\ln \left(\alpha_{\mathrm{w}}\right) / \mathrm{exp}(\mathrm{A}+\mathrm{BT})\right]^{-1 / \mathrm{c}}$ \\
Modified Chung-Pfost & $\mathrm{X}=-1 / \mathrm{C} \ln \left[-(\mathrm{T}+\mathrm{B}) / \mathrm{A} \ln \left(\alpha_{\mathrm{w}}\right)\right]$ & $(5)$ \\
$\mathrm{GAB}$ & $\mathrm{X}=\mathrm{X}_{\mathrm{m}} \mathrm{C}_{\mathrm{G}} \mathrm{K} \alpha_{\mathrm{w}} /\left(1-\mathrm{K} \alpha_{\mathrm{w}}\right)\left(1-\mathrm{k} \alpha_{\mathrm{w}}+\mathrm{C}_{\mathrm{G}} \mathrm{K} \alpha_{\mathrm{w}}\right)$ & $(6)$ \\
\hline
\end{tabular}

where $A, B, C, C_{G}, K, K_{l}, K_{2}, N_{l}, N_{2}$ and $X_{m}$ are parameters of the equations; $T$ is temperature $\left({ }^{\circ} \mathrm{C}\right) ; X$ is equilibrium moisture content (d.b.) and $\alpha$ is the water activity

The criteria used to assess the excellence of the adjustment were the values of the coefficient of determination $\left(\mathrm{R}^{2}\right)$, mean relative error $P$ (Equation 7), and analysis of the graphs of residuals (MENKOV, 2000).

$P=100 / N \sum\left|Y-Y^{\prime}\right| / Y$

where: $N$ represents the number of experiments; and $Y$ and $Y^{\prime}$ are the experimental and the predicted values, respectively. Typically, the mathematical adjustments with mean relative errors under $10 \%$ are considered satisfactory (SIQUEIRA; RESENDE; CHAVES, 2013).

The net isosteric heat of desorption $\left(\mathrm{q}_{\mathrm{st}}\right)$ was estimated from the Clausius-Clapeyron equation, as Equation 8 indicates (SORMOLI; LANGRISH, 2015).

$$
\left[d \ln \left(\alpha_{w}\right) / d(1 / T)\right]_{X}=-q_{s} / R
$$

where: $q_{s t}$ the net heat of sorption is given in $\mathrm{kJ} \mathrm{mol}^{-1}, T$ is the absolute temperature in Kelvin, $X$ is the content of the dry-base equilibrium moisture (d.b.), $a_{w}$ is the water activity and $R$ is the universal gas constant $\left(8.314 \mathrm{~J} \mathrm{~mol}^{-1} \mathrm{~K}^{-1}\right)$.

The differential enthalpy, often referred to as isosteric heat of sorption, is an indicator of the state of the water absorbed by the solid material. The total isosteric heat of sorption $\left(Q_{\mathrm{st}}\right)$, in $\mathrm{kJ} \mathrm{mol}^{-1}$, is defined as the sum of net isosteric heat of sorption and the heat of water vaporization at the system temperature (Equation 9).

$Q_{s t}=q_{s t}+\lambda_{v a p}$

The latent heat of free water vaporization $\lambda_{\text {Vap }}$, at average work temperature $\left(42.59 \mathrm{~kJ} \mathrm{~mol}^{-1}\right)$, was obtained from Equation 10, with $\mathrm{T}$ in Celsius.

$\lambda_{\text {vap }}=44 \cdot 72-0.03 T-9 \cdot 2 \cdot 10^{-5} T^{2}$

The differential entropy $\left(S_{d}\right)$ is related to the number of sorption sites at a certain energy level intrinsic to the biological material, and it can be used to obtain information about streamlining energy during product processing. The differential entropy $\left(S_{d}\right)$, in kJ mol-1 $\mathrm{K}^{-1}$, was determined from the Gibbs-Helmholtz equation, given by Equation 11 (ALPIZAR-REYES et al., 2017).

$S_{d}=q_{s t}-G / T$

The Gibbs free energy $(\Delta G)$, in $\mathrm{kJ} \mathrm{mol}^{-1}$, is calculated by Equation 12: 
$\Delta G=-R T \ln \left(\alpha_{w}\right)$

The effects of changes in the water sorption on the free energy are normally followed by changes in the values of enthalpy and entropy Thus, replacing Equation 12 in Equation 11, and reorganizing, we have:

$-\ln \left(\alpha_{w}\right)=q_{s t} / R T-S / R$

The theory of enthalpy-entropy compensation or the isokinetics relationship is used to assess the physical and chemical phenomena, which prevail in the sorption processes. This theory proposes a linear relationship between $q_{s t}$ and $S_{d}$, given by Equation 14 (MOREIRA et al., 2008):

$q_{s t}=T_{B}\left(S_{d}\right)+\Delta G$

where: $T_{B}$ represents the isokinetic temperature given in Kelvin and $\Delta \mathrm{G}$ the Gibbs free energy at isokinetic temperature $\left(\mathrm{kJ} \mathrm{mol}^{-1}\right)$. The isokinetic temperature represents the temperature in which all chain reactions occur at in the same rate. The compensation theory is assessed from the linear correlation of Equation 8, which involves the assessment of the isokinetic temperature $\left(T_{B}\right)$ towards the harmonic average temperature $T_{h m}$ (Equation 15):

$T_{h m}=n / \sum_{i=1}^{n}(1 / T)$

where: $n$ is the total number of isotherms and $\mathrm{T}$ is the absolute temperature at 40,60 , and $80^{\circ} \mathrm{C}$. Compensation theory can only be applied if $T_{B}>T_{h m}$ or enthalpy leads the process; otherwise, the process will be controlled by entropy (ALVES; FÓZ; NICOLETI, 2015; MADAMBA; DRISCOLL; BUCKLE, 1996).

\section{RESULTS AND DISCUSSION}

The equilibrium moisture of desorption data, obtained experimentally for the flaxseeds at the three temperatures assessed, are presented in Table 3. The variation among quadruplicate samples was less than $2 \%$ for most samples. For these data, the models listed in Table 2 were adjusted to choose the one that best represented the drying phenomenon, so that the moisture contents responded well to temperature variations.

A non-linear regression analysis was performed with desorption isotherm experimental data using the six mathematical models described in Table 3. The values obtained for the model parameters were adjusted at different temperatures, and the respective values of coefficient of determination $\left(\mathrm{R}^{2}\right)$, mean relative error $(P)$, and the analysis of graphs of residuals are summarized in Table 4.
Based on Table 4, we observe that among the mathematical models assessed, those which best described the flaxseed moisture desorption data were the GAB and Peleg as they presented values smaller than $10 \%$ to the mean relative error, coefficient of determination around $99 \%$, and distribution of randomness of residuals for all the temperatures studied. Similar behavior was also observed in other works using seeds as raw material (ALVES; FÓZ; NICOLETI, 2015; FREITAS et al., 2016). Mazza, Jayas, and White (1980) in their study on flax seed hygroscopicity report the best efficiency of the GAB model in describing equilibrium moisture content data compared to other models.

Considering that the GAB model has a theoretical basis, while the other models are empirical and semiempirical, it is largely applied to describe equilibrium moisture isotherms in bioproducts, and was recommended by the European Project COST'90. We used this model to estimate the thermodynamic properties of the flaxseeds (SINGH; KUMARI, 2014; SPIESS; WOLF, 1983).

The value of the monolayer moisture content $\left(X_{m}\right)$ is important as it may be related to the initiation of a series of grain deterioration chemical reactions and it also indicates the amount of water that is strongly linked to active sorption sites. Generally, the equilibrium water content is where the grain may remain stable.

Table 4 verifies that $\mathrm{Xm}$ for the GAB model decreased with increasing temperature, varying from 0.0378 to 0.0233 (d.b.), which indicates that flaxseeds can be conserved for long periods at moisture contents below 0.0378 (d.b.), taking into account that below this level the water does not act as solvent, as it is biologically inert.

The results obtained from the GAB mathematical model are graphically represented in Figure 1, which clearly shows the influence of temperature on flaxseed water activity. The moisture desorption isotherms for the flaxseeds, illustrated in Figure 1, are sigmoid in shape, which is typical behavior for Type II isotherms, according to BET theory, suggesting the existence of moisture adsorbed in multilayers (ANDRADE; LEMUS; PEREZ, 2011).

It is also verified that the equilibrium moisture flaxseed desorption content decreased with the increase in temperature to a constant water activity, because of the high excited state of water molecules at high temperatures, decreasing the attraction forces between the molecules. This behavior was observed in other agricultural products (BELGHITH; AZZOUZ; ELCAFSI, 2016; CHISTÉ et al., 2015). Figure 1 also verifies the exponential behavior of desorption isotherms for all temperatures studied from water activity values (aw) of 0.6. This behavior suggests that from this value on, a small increase in the relative 
Table 3 - Data for equilibrium moisture of desorption for the flaxseeds

\begin{tabular}{|c|c|c|c|c|c|}
\hline \multicolumn{2}{|c|}{$40^{\circ} \mathrm{C}$} & \multicolumn{2}{|c|}{$60^{\circ} \mathrm{C}$} & \multicolumn{2}{|c|}{$80^{\circ} \mathrm{C}$} \\
\hline aw & X (\% d.b.) & aw & X (\% d.b. $)$ & aw & X (\% d.b. $)$ \\
\hline 0.063 & $3.63 \pm 0.04$ & 0.036 & $2.25 \pm 0.06$ & - & - \\
\hline 0.112 & $3.92 \pm 0.02$ & 0.109 & $2.26 \pm 0.04$ & 0.105 & $1.86 \pm 0.01$ \\
\hline 0.316 & $5.37 \pm 0.03$ & 0.293 & $4.00 \pm 0.05$ & 0.260 & $3.30 \pm 0.02$ \\
\hline 0.433 & $6.39 \pm 0.01$ & 0.421 & $4.57 \pm 0.01$ & 0.411 & $3.87 \pm 0.03$ \\
\hline 0.710 & $8.92 \pm 0.05$ & 0.673 & $6.20 \pm 0.02$ & 0.652 & $5.26 \pm 0.04$ \\
\hline 0.747 & $10.69 \pm 0.04$ & 0.745 & $8.58 \pm 0.03$ & 0.763 & $7.79 \pm 0.05$ \\
\hline 0.823 & $13.29 \pm 0.01$ & 0.802 & $10.14 \pm 0.03$ & 0.789 & $8.39 \pm 0.06$ \\
\hline
\end{tabular}

where $\mathrm{a}_{\mathrm{w}}$ is water activity; $\mathrm{X}$ is equilibrium moisture in a dry base (d.b.); - values $<0.01$

Table 4 - Values obtained for desorption isotherms model parameters adjusted at different temperatures

\begin{tabular}{|c|c|c|c|c|c|c|c|c|}
\hline \multirow{2}{*}{ Models } & \multirow{2}{*}{ Temperature $\left({ }^{\circ} \mathrm{C}\right)$} & \multicolumn{4}{|c|}{ Parameters } & \multirow{2}{*}{$\mathrm{R}^{2}(\%)$} & \multirow{2}{*}{$\mathrm{P}(\%)$} & \multirow{2}{*}{ Residues } \\
\hline & & $\mathrm{K}_{1}$ & $\mathrm{~N}_{1}$ & $\mathrm{~K}_{2}$ & $\mathrm{~N}_{2}$ & & & \\
\hline \multirow{4}{*}{ Peleg } & 40 & 7.703 & 0.88 & 21.64 & 6.472 & 99.72 & 3.40 & $\mathrm{R}$ \\
\hline & 60 & 5.815 & 0.338 & 22.037 & 6.864 & 99.35 & 8.03 & $\mathrm{R}$ \\
\hline & 80 & 5.802 & 0.467 & 35.787 & 9.957 & 99.72 & 4.10 & $\mathrm{R}$ \\
\hline & & A & \multicolumn{2}{|c|}{ B } & $\mathrm{C}$ & & & \\
\hline \multirow{3}{*}{ Modified Oswin } & 40 & 4.324 & \multicolumn{2}{|c|}{0.009} & 2.899 & 98.32 & 5.16 & $\mathrm{~T}$ \\
\hline & 60 & 1.681 & \multicolumn{2}{|c|}{0.011} & 2.479 & 97.94 & 10.5 & $\mathrm{R}$ \\
\hline & 80 & 2.933 & \multicolumn{2}{|c|}{0.004} & 2.275 & 98.22 & 7.31 & $\mathrm{R}$ \\
\hline \multirow{3}{*}{ Modified Henderson } & 40 & 0.0002 & \multicolumn{2}{|c|}{-7.53} & 1.272 & 88.94 & 42.8 & $\mathrm{~T}$ \\
\hline & 60 & 0.0001 & \multicolumn{2}{|c|}{-2.60} & 1.499 & 95.45 & 20.1 & $\mathrm{~T}$ \\
\hline & 80 & 0.0004 & \multicolumn{2}{|c|}{-0.58} & 0.997 & 84.13 & 30.8 & $\mathrm{~T}$ \\
\hline \multirow{3}{*}{ Modified Halsey } & 40 & 4.310 & \multicolumn{2}{|c|}{0.006} & 1.391 & 85.91 & 21.0 & $\mathrm{~T}$ \\
\hline & 60 & -5.988 & \multicolumn{2}{|c|}{0.025} & 1.694 & 99.06 & 7.80 & $\mathrm{R}$ \\
\hline & 80 & -4.706 & \multicolumn{2}{|c|}{0.018} & 1.627 & 98.77 & 5.76 & $\mathrm{R}$ \\
\hline \multirow{4}{*}{ Modified Chung-Pfost } & 40 & 0.404 & \multicolumn{2}{|c|}{-313} & 0.264 & 97.30 & 10.8 & $\mathrm{R}$ \\
\hline & 60 & 0.461 & \multicolumn{2}{|c|}{-333} & 0.352 & 96.36 & 14.7 & $\mathrm{R}$ \\
\hline & 80 & 0.466 & \multicolumn{2}{|c|}{-353} & 0.363 & 97.03 & 10.4 & $\mathrm{R}$ \\
\hline & & $X_{m}$ & \multicolumn{2}{|c|}{$\mathrm{K}$} & $\mathrm{C}_{\mathrm{G}}$ & & & \\
\hline \multirow{3}{*}{ GAB } & 40 & 3.78 & \multicolumn{2}{|c|}{0.862} & 192.9 & 99.42 & 3.65 & $\mathrm{R}$ \\
\hline & 60 & 2.64 & \multicolumn{2}{|c|}{0.920} & 107.4 & 99.01 & 8.21 & $\mathrm{R}$ \\
\hline & 80 & 2.33 & \multicolumn{2}{|c|}{0.914} & 40.53 & 99.41 & 8.16 & $\mathrm{R}$ \\
\hline
\end{tabular}

where $A, B, C, C_{G}, K, K_{1}, K_{2}, N_{1}, N_{2}$ and $X_{m}$ are parameters of the equations; $R^{2}$ is the coefficient of determination; $P$ is the mean relative error; $R$ : Random and $\mathrm{T}$ : Tendentious

room moisture provokes a considerable increase in the equilibrium moisture of the flaxseeds, affecting the quality of the seeds in storage places where the relative moisture is above $60 \%$.
In Figure 2, the behavior of the integral heat of desorption $\left(Q_{s t}\right)$ toward the moisture content of the flaxseeds is illustrated showing the increase in $Q_{s t}$ with the decrease in equilibrium moisture. 
Figure 1 - Moisture desorption isotherms of the flaxseeds at different temperatures adjusted to the GAB model

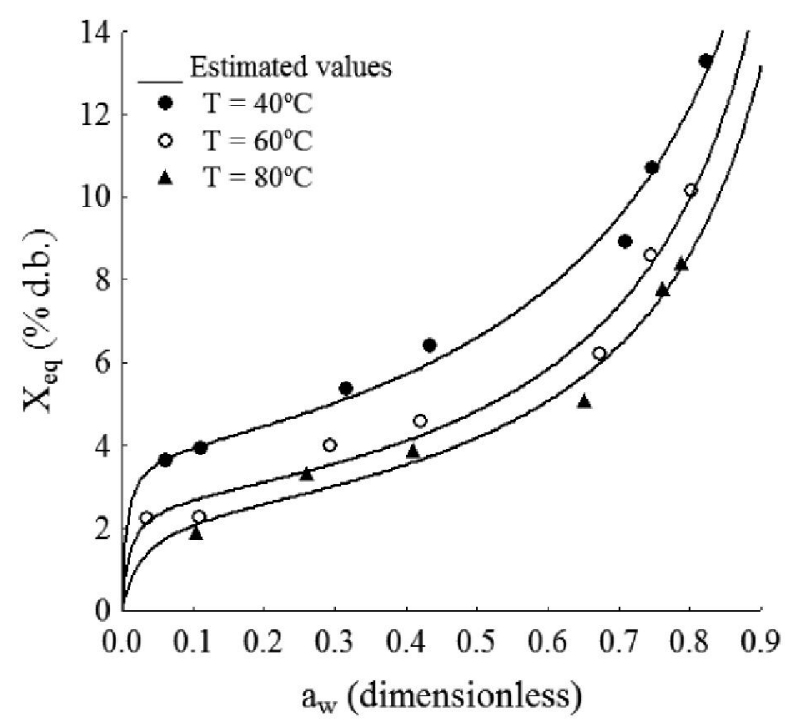

The high value of net isosteric desorption heat at low moisture content indicates highly active polar sites on the seeds surfaces, that should be covered with a monomolecular layer of water molecules. The maximum observed variation was small in relation to latent heat of vaporization of pure water $\left(\lambda_{\text {Vap }}=42.59 \mathrm{~kJ} \mathrm{~mol}^{-1}\right)$, suggesting that sorbed water depends little on the interaction energy between the water molecules and the solid matrix of the products, in the temperature range studied.

Similar differential enthalpy results were obtained as in sucupira-branca (Pterodon emarginatus Vogel) fruits, cucumber seeds, and different kinds of food products (CLADERA-OLIVERA et al., 2008; CORRÊA et al., 2015; OLIVEIRA et al., 2017).

The values of integral isosteric heats for flaxseeds in the equilibrium moisture content range of 0.02 to 0.1 (d.b.) varied from 104.17 to $47.24 \mathrm{~kJ} \mathrm{~mol}^{-1}$, respectively.

Equation 16 represents the mathematical model for experimental values of the integral isosteric heat of desorption $\left(Q_{s t}\right)$, in $\mathrm{kJ} \mathrm{mol}^{-1}$, toward the equilibrium moisture content $X$ ( $\%$ d.b.). It is observed that the equation used is satisfactory to describe the phenomenon, presenting high significance of its parameters and of the coefficient of determination $\mathrm{R}^{2}$ of $99.33 \%$.

$Q_{s t}=42.59+127.07 \exp (-0.3547 X)$

The results of the differential entropy $\left(S_{d}\right)$ are illustrated in Figure 3, which shows an increase in $\mathrm{Sd}$ toward the equilibrium moisture content, that is, this thermodynamic property increases exponentially with the
Figure 2 - Isosteric heat of sorption toward equilibrium moisture content for the desorption of flaxseeds

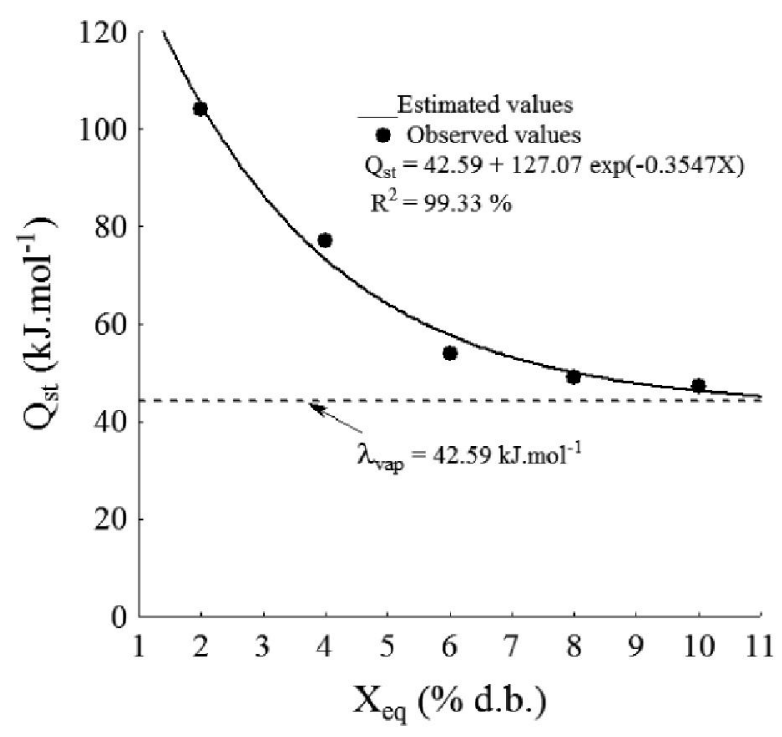

increase in equilibrium moisture content, indicating the state of mobility of the water molecules in the product.

This behavior suggests that at low moisture content, the water molecules are strongly bonded to the surface of the sorbate and, thus, have low degree of freedom, meaning there are internal restrictions, resulting in the decreasing entropy. However, at high moisture contents, the molecules are adsorbed in multilayers, causing higher configurational freedom, improving the disorder of the system, and consequently increasing the sorption entropy (RIZVI, 2005).

Figure 3 - Differential entropy of desorption toward the equilibrium moisture content to the flaxseeds

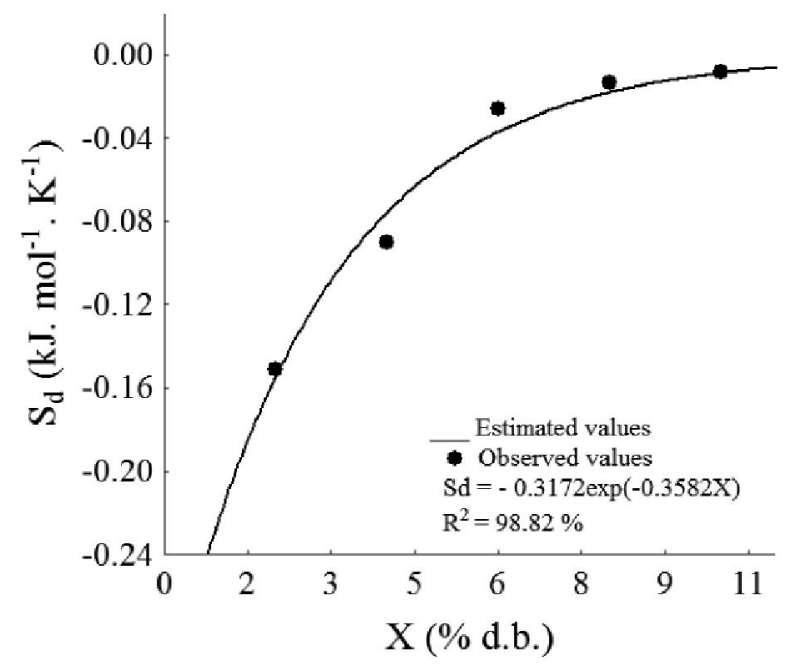


This calculation is important because when it is associated to the differential desorption entropy, it results in Gibbs free energy (Equation 14), which is a thermodynamic function of state and represents the maximum amount of energy liberated in a process at constant temperature and pressure.

Equation 17 represents the mathematical description of the experimental values of differential entropy for the flaxseeds toward the equilibrium moisture content, with $\mathrm{R}^{2}$ of 98.82\% demonstrating the excellence of the proposed model.

$S_{d}=-0.3172 \exp (-0.3582 X)$

In Figure 4 it is shown the linear correlation between qst and $S_{d}$, whose $\mathrm{R}^{2}$ was $99.91 \%$, which indicates the existence of chemical compensation between these thermodynamic parameters.

Figure 4 - Correlation between differential enthalpy $\left(\mathrm{q}_{\mathrm{st}}\right)$ and differential entropy $\left(S_{d}\right)$ of desorption for the flaxseeds

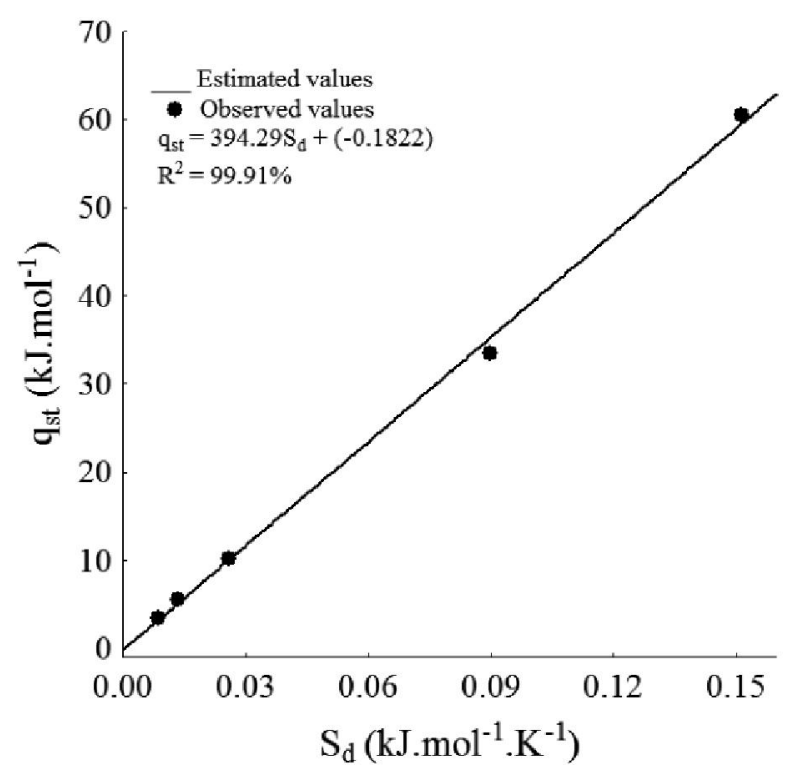

The results were correlated according to Equation 8 and the isokinetic temperature $\left(T_{B}\right)$ calculated was $394.29 \mathrm{~K}$. This temperature was higher than the harmonic average (Thm) calculated by Equation 15, resulting in a value of $332.41 \mathrm{~K}$. Therefore, $T_{B}>T_{h m}$, indicating that the moisture desorption process in flaxseeds is controlled by enthalpy.

\section{CONCLUSIONS}

1. The flaxseed adsorption isotherms were sigmoidally shaped, which is typical of Type II isotherms according to the BET theory, indicating moisture adsorbed in multilayers. The mathematical models GAB and Peleg satisfactorily presented the experimental data for the three temperatures studied, demonstrating excellent correlation to the statistical values: mean relative error (D < 10\%), coefficient of determination $\left(\mathrm{R}^{2}>99 \%\right)$, and distribution of randomness residuals;

2. The equilibrium moisture decreased with the temperature increase of the whole aw range assessed, indicating changes in the interaction mechanism of water with the seed surface sites. The values of moisture in the monolayer $\left(X_{m}\right)$, estimated by the GAB model, had an average value of 0.029 (d.b.);

3. The reduction in equilibrium moisture content improves the increase in energy necessary to remove water from the seeds, represented by values of the integral isosteric heat of desorption, which varied from 47.24 to $104.17 \mathrm{~kJ} \mathrm{~mol}^{-1}$. However, the differential entropy increases toward the equilibrium moisture content. The isosteric heat and the desorption entropy demonstrate similar behavior with a change of form near an equilibrium moisture content of 0.06 (d.b.), and the compensation theory was applied successfully, indicating that the process of desorption of flaxseeds is controlled by enthalpy.

\section{ACKNOWLEDGEMENTS}

The authors gratefully acknowledge financial aid from the CNPq.

\section{REFERENCES}

ALPIZAR-REYES, E. et al. Thermodynamic sorption properties and glass transition temperature of tamarind seed mucilage (Tamarindus indica L.). Food and Bioproducts Processing, v. 101, p. 166-176, 2017.

ALVES, T. P.; FÓZ, H. D; NICOLETI, J. F. Isotermas de dessorção de pimentão verde e energia envolvida no processo. Brazilian Journal of Food Technology, v. 18, n. 2, p. 137-145, 2015.

ANDRADE, P. R. D.; LEMUS, M. R.; PEREZ, C. C. E. Models of sorption isotherms for food: uses and limitations. Vitae, v. 18, n. 3, p. 325-334, 2011.

BELGHITH, A.; AZZOUZ, S.; ELCAFSI, A. Desorption isotherms and mathematical modeling of thin layer drying kinetics of tomato. Heat Mass Transfer, v. 52, p. 407-419, 2016.

BOTHEJU, W. S.; AMARATHUNGE, K. S. P.; ZIYAD MOHAMED, M. T. Modeling moisture desorption isotherms 
and thermodynamic properties of fermented tea dhool (Camellia sinensis var. assamica). Drying Technology, v. 26, n. 10, p. 1294-1299, 2008.

CABEZA, L. F.; SOLÉ, A.; BARRENECHE, C. Review on sorption materials and technologies for heat pumps and thermal energy storage. Renewable Energy, v. 110, p. 3-39, 2017.

CHISTÉ, R. C. et al. Hygroscopic behaviour of cassava flour from dry and water groups. Ciência Rural, v. 45, n. 8, p. 15151521,2015 .

CHOO, W. S.; BIRCH, J.; DUFOUR, J. P. Physicochemical and quality characteristics of cold-press flaxseed oils. Journal of Food composition and Analysis, v. 20, n. 3, p. 202-211, 2007.

CLADERA-OLIVERA, F. et al. Thermodynamic properties of moisture desorption of raw pinhão (Araucaria angustifólia seeds). International Journal of Food Science and Technology, v. 43, n. 5, p. 900-907, 2008.

CORRÊA, P. C. et al. Moisture desorption isotherms of cucumber seeds: modeling and thermodynamic properties. Journal of Seed Science, v. 37, n. 3, p. 218-225, 2015.

FREITAS, M. L. F. et al. Sorption isotherms and thermodynamic properties of grated Parmesan cheese. International Journal of Food Science \& Technology, v. 51, n. 1, p. 250-259, 2016.

GONELI, A. L. et al. Moisture sorption isotherms of castor beans. Part 2: Thermodynamic properties. Revista Brasileira de Engenharia Agrícola e Ambiental, v. 20, n. 8, p. 757-762, 2016.

GREENSPAN, L. Humidity fixed points of binary saturated aqueous solutions. Journal of Research of the National Bureau of Standards - A. Physics and Chemistry, v. 18, n. 1, p. 89-96, 1977.

HORWITZ, W. (ed.). Official Methods of Analysis of the AOAC International. 18 th ed. Gaithersburg: Association of Official Analytical Chemists, 2005. 771 p.

KAJLA, P.; SHARMA, A.; SOOD, D. R. Flaxseed: a potential functional food source. Journal of Food Science and Technology, v. 52, n. 4, p. 1857-1871, 2015.

LABUZA T. P. Standard procedure for isotherm determination. Cereal Foods World (USA), v. 28, n. 4, p. 258, 1983.
MADAMBA, P. S.; DRISCOLL, R. H.; BUCKLE, K. A. Enthalpy-entropy compensation models for sorption and browning of garlic. Journal of Food Engineering, v. 28, n. 2, p. 109-119, 1996.

MAZZA, G.; JAYAS, D. S.; WHITE, N. D. G. Moisture sorption isotherms of flax seed. Transactions of the ASAE, v. 33, n. 4, p. 1313-1318, 1990.

MENKOV, N. D. Moisture sorption isotherms of chickpea seeds at several temperatures. Journal of Food Engineering, v. 45, n. 4, p. 189-194, 2000.

MIANOWSKI, A.; URBAŃCZYK, W. Enthalpy-entropy compensation for isosteric state adsorption at near ambient temperatures. Adsorption, v. 23, n. 6, p. 831-846, 2017.

MOREIRA, R. et al. Thermodynamic analysis of experimental sorption isotherms of loquat and quince fruits. Journal of Food Engineering, v. 88, n. 4, p. 514-521, 2008.

OLIVEIRA, D. E. C. de et al. Hygroscopicity of 'sucupirabranca'(Pterodon emarginatus Vogel) fruits. Revista Brasileira de Engenharia Agrícola e Ambiental, v. 21, n. 4, p. 285-289, 2017.

RIZVI, S. S. H. Thermodynamics properties of foods in dehydratation. In: RAO, M. A.; RIZVI, S. S. H.; DATTA, A. K. Engineering Properties of Foods. 3: ed. New York: Academic Press, 2005. p. 239-326.

SINGH, A. K.; KUMARI, N. Moisture sorption isotherm characteristics of ground flaxseed. Journal of Food Processing \& Technology, v. 5, n. 4, 2014.

SIQUEIRA, V. C.; RESENDE, O.; CHAVES, T. H. Mathematical modelling of the drying of jatropha fruit: an empirical comparison. Revista Ciência Agronômica, v. 44, n. 2, p. 278-285, 2013.

SORMOLI, M. E.; LANGRISH, T. A. G. Moisture sorption isotherms and net isosteric heat of sorption for spray-dried pure orange juice powder. LWT- Food Science and Technology, v. 62 , p. 875-882, 2015.

SPIESS, W. E. L.; WOLF, W. F. The results of the COST 90 project on water activity. In: JOWITT, R. (ed.). Physical properties of foods. London: Applied Science Publishers, p. 6591, 1983. 